\title{
Studies on Physico-chemical Parameters of Kanigiri Reservoir, Nellore District, Andhra Pradesh
}

\author{
K. Chalapathi ${ }^{1}$, K. Madhavi ${ }^{1}$, D. Ramalingaiah ${ }^{1}$, N. Jesintha ${ }^{1}$, Adnan Amin ${ }^{1 *}$, G. Gowri ${ }^{1}$, \\ Boda Satyanarayana $^{2}$, Sajhunnneesa Thirunilath ${ }^{3}$ and Jeshwanthi Jaini ${ }^{4}$ \\ ${ }^{1}$ College of Fishery Science, Muthukur, Nellore, Andhra Pradesh, India \\ ${ }^{2}$ WBUAFSCE, Kolkata, India \\ ${ }^{3}$ Central Marine Fisheries Research Institute, Kochi, Kerala, India \\ ${ }^{4}$ Central Institute of Fishery Education, Mumbai, India \\ *Corresponding author
}

\begin{tabular}{|c|c|}
\hline & A B S T R A C T \\
\hline Keywords & \multirow{4}{*}{$\begin{array}{l}\text { Present work was carried out to assess the physico-chemical parameters of water } \\
\text { samples of Kanigiri reservoir of River Penna during November } 2016 \text { to May } 2017 \\
\text { for a period of seven months. Various water quality parameters including Air } \\
\text { temperature, Water temperature, pH, Turbidity, total alkalinity, total hardness, } \\
\text { Free } \mathrm{CO}_{2} \text {, DO, BOD, Chlorides, TDS and total ammonia were estimated whereas, } \\
\text { correlation coefficients between different parameters of both the stations upstream } \\
\text { and downstream were also analysed. Water quality of the reservoir is in } \\
\text { accordance with the drinking water standards with respect to turbidity, pH, TDS, } \\
\text { total alkalinity, total hardness and total ammonia except for BOD. }\end{array}$} \\
\hline $\begin{array}{l}\text { Physico-chemical } \\
\text { parameters, } \\
\text { Kanigiri reservoir, } \\
\text { Water quality }\end{array}$ & \\
\hline Article Info & \\
\hline $\begin{array}{l}\text { Accepted: } \\
\text { 08 July } 2018 \\
\text { Available Online: } \\
10 \text { August } 2018\end{array}$ & \\
\hline
\end{tabular}

\section{Introduction}

Earth, the water planet, is beset by water problems. The world is fast growing with its technologies and ever increasing population, so the dependence as well as exploitation of freshwater resources is also increasing rapidly. The distribution of water resources over the complete land mass of Earth is uneven and quite unrelated to population spread or economic development. The most important drivers of water use are population and economic development, and also changing societal views on the value of water. The latter refers to such issues as the prioritization of domestic and industrial water supply over irrigation water supply, and the extent to which water-saving technologies and water pricing are adopted.

Reservoirs are storage structures for surface water sources and exhibit wide variations in 
their morphometric limno-chemical and biological characteristics. The physicochemical and biological characteristics of water in reservoirs are mostly influenced by the seasonal variations in river water inflow, water level fluctuations and the hydraulic residence time (Gikas et al., 2009). The Ministry of Agriculture, Government of India has classified reservoirs as small $(<1000 \mathrm{ha})$, medium (1,000 to 5,000 ha) and large $(>5000$ ha) for the purpose of fisheries management (Srivastava et al., 1985).

Reservoirs are open, unstable, heterogeneous and interactive systems with characteristics typical for lakes as well as for rivers. In general, the environmental conditions in reservoirs are intermediate between those of rivers and lakes. These differences are reflected in their morphology, hydrology, physico-chemical and biological characteristics. India has a total of 19,370 reservoirs, of which 19,134 are small, 180 are medium and 56 are large (Dixitulu, 1999; Sugunan and Sinha, 2000).

Reservoirs are the basis for large-scale water management systems and this very role of them is witnessed in adjusting natural runoff with its seasonal variations and climatic irregularities to meet the pattern and demand for irrigated agriculture, power generation, domestic and industrial water supply and navigation (ICOLD, 1998). Reservoirs serves as best management tools in providing a dynamic solution to two (02) different problems with respect to the spatial distribution of fresh water resources i.e., the water that is going to have a severe negative impact in some areas by way of floods and inundation, now by virtue of having reservoirs, the same is turning in to a solution for other needy areas in mitigating catastrophic droughts. The construction of surface reservoirs can also bring about needful transformations in the temporal distribution of river runoff thereby providing a solution to scarcity of water resources during the low flow limiting periods and dry seasons.

River Pennar was originated from the Chennakesava hills of the Nandidurg range in Chikkaballapura district of Karnataka. It is also known as 'Uttara Pinakini' and is one of the major east flowing rivers of the South India that drains in to bay of Bengal. It is the third major river in Andhra Pradesh after Godavari and Krishna.

\section{Materials and Methods}

\section{Study area}

Kanigiri Reservoir is the main terminal storage reservoir on the left (northern) side of Sangam anicut. It gets its supplies from not only Sangam anicut but also from its own catchment area. The ayacut under the reservoir is served mainly by two channels - namely Southern Channel and Eastern Channel. The surplus water of the reservoir forms Malidevi Drain, Which also absorbs the field drainage and again supplies water for irrigating the fields on either side of it. Pyderu escape channel serves both as escape channel during floods and also as an irrigation channel feeding an extent of 5,400 acres. A pick-up anicut was constructed across this channel near Talamanchi (V) to feed Allur large Tank and Allur Ramanna Tanks (Fig. 1).

Sampling was carried at fortnightly intervals during the period from November-2016 to May-2017. Surface sampling was done in all the selected stations. On the basis of the local rainfall conditions, the study period consisted of monsoon (November and December), winter (January and February) and summer (March, April and May) seasons. We identified two sampling stations one representing the upstream and other is downstream based on the flow of water. The 
physico-chemical parameters such as temperature, $\mathrm{pH}$, dissolved oxygen, total alkalinity, total hardness and transparency were analyzed fortnightly.

\section{Meteorology}

\section{Rainfall}

The amount of rainfall received in the region during the study period was obtained from the Irrigation Department, Nellore.

\section{Air Temperature}

Air temperature was recorded at each station at the beginning of the sampling using a standard mercury centigrade thermometer to the nearest $0.1^{\circ}$ and expressed in degree Celsius.

\section{Hydrography}

Water samples were collected from the two selected sampling stations for a period of 7 months (November, 2016 to May, 2017) at fortnightly intervals in the early hours of the day between 7.00 AM to 9.00 AM. At each station, samples of surface (at a depth of one foot) waters were collected in duplicate and mixed together so as to portray the average condition in the respective area. Iodine treated double stoppered polythene bottles were used for collection of water samples.

\section{Water temperature}

Surface water temperatures were recorded immediately after the collection using a standard mercury centigrade thermometer to the nearest $0.1^{\circ}$ and expressed in degree Celsius.

\section{Dissolved oxygen}

Water samples for estimation of dissolved oxygen were collected in clean $125 \mathrm{~mL}$ stoppered glass bottles carefully avoiding air bubbles. The samples were then fixed immediately with Winkler's reagents.

\section{Carbon dioxide}

Free $\mathrm{CO}_{2}$ content was estimated by the titrimetric method using phenolphthalein indicator and sodium hydroxide.

\section{Biochemical Oxygen Demand (BOD)}

For the estimation of Biochemical Oxygen Demand, the water samples were collected in $300 \mathrm{~mL}$ oxygen bottles carefully avoiding air bubbles.

\section{Total ammonia}

Water samples were collected in $150 \mathrm{~mL}$ amber coloured glass bottles and fixed following the phenol-hypochlorite method as described by Parsons et al., (1989).

\section{Laboratory analysis}

\section{Turbidity}

Turbidity of water samples was estimated using digital Nephalometer (Model 341, EI) and expressed as NTU.

\section{Total Dissolved Solids (TDS)}

Gravimetric estimation of TDS was carried out by following the method described in APHA (2005) and the results were expressed in $\mathrm{mg} / \mathrm{L}$.

\section{pH (Potentia Hydrogeni)}

$\mathrm{pH}$ of water samples was measured potentiometrically using digital $\mathrm{pH}$ meter (Digital pH Meter-111, EI).

\section{Chlorides}

Chloride content was estimated by titrating the 
water sample with silver nitrate using potassium chromate as indicator and expressed in terms of $\mathrm{mg} / \mathrm{L}$.

\section{Results and Discussion}

\section{Meteorology}

\section{Rainfall}

Maximum rainfall was observed during the month of December and no rainfall was observed during five months i.e., from January to May against seven (07) months of the present study. During the present investigation, the area experienced higher rainfall during November (N-E monsoon), which is in accordance with the observation made by Perumal (1993).

\section{Air temperature}

A significant variation in the value of air temperature has been observed due to the influence of climatological parameters. In general, the lower values of air temperature were observed in monsoon and winter, in comparison to summer season.

Air temperature at upstream station was fluctuated between $27.8{ }^{\circ} \mathrm{C}$ in the month of November (monsoon) and $32.4{ }^{\circ} \mathrm{C}$ in the month of May (summer) with a variation of $4.6^{\circ} \mathrm{C}$ and a study period Mean (Mean \pm SD) of $29.76 \pm 2.00{ }^{\circ} \mathrm{C}$ (Table 1). Whereas in downstream air temperature ranged from 27.9 ${ }^{\circ} \mathrm{C}$ in the month of December (monsoon) to $32.7^{\circ} \mathrm{C}$ in the month of May (summer) with a variation of $4.8^{\circ} \mathrm{C}$ and study period Mean (Mean $\pm \mathrm{SD}$ ) of $30.04 \pm 1.95^{\circ} \mathrm{C}$ (Table 2).

During the study period air temperatures recorded at Kanigiri reservoir ranged from $27.80^{\circ} \mathrm{C}$ to $32.70^{\circ} \mathrm{C}$ with a Mean $\pm \mathrm{SD}$ of 29.9 $\pm 1.91^{\circ} \mathrm{C}$. Similar trend in air temperature was noticed by Basavaraja et al., (2014) while investigating on Anjanapura reservoir $\left(28.16^{\circ} \mathrm{C}\right.$ to $33.5^{\circ} \mathrm{C}$ ) and Mohammad et al., (2015) while working on Wyra reservoir $\left(22.8^{\circ} \mathrm{C}\right.$ to $\left.33.7^{\circ} \mathrm{C}\right)$.

\section{Hydrography}

\section{Water temperature}

Water temperature is of enormous significance as it regulates the biological activities and governs the solubility of gases in water. Temperature of water depends upon time of collection, water depth besides solar radiation, climate and topography. A significant variation in the value of water temperature has been observed due to the influence of climatological parameters. In general, the lower values of air temperature were observed in monsoon and winter, in comparison to summer season.

Water temperature at upstream station fluctuated between $27.5^{\circ} \mathrm{C}$ February (winter) and $32.3{ }^{\circ} \mathrm{C}$ in the month of May (summer) with a variation of $4.8^{\circ} \mathrm{C}$ and a study period Mean (Mean \pm SD) of $29.56 \pm 2.02{ }^{\circ} \mathrm{C}$ (Table $1)$. Whereas in downstream water temperature ranged from $27.7{ }^{\circ} \mathrm{C}$ in the month of December (monsoon) to $32.5^{\circ} \mathrm{C}$ in the month of May (summer) with a variation of $4.8^{\circ} \mathrm{C}$ and study period Mean (Mean \pm SD) of 29.81 $\pm 1.93{ }^{\circ} \mathrm{C}$. (Table 2$)$

During the study period, it varied between $27.5^{\circ} \mathrm{C}$ and $32.5^{\circ} \mathrm{C}$ (Mean \pm SD of $29.68 \pm$ $1.91^{\circ} \mathrm{C}$ ). Similar type of observations was made by Thirupathaiah et al., (2012) in case of Lower Manair reservoir $\left(24^{\circ} \mathrm{C}\right.$ to $\left.30.0^{\circ} \mathrm{C}\right)$. Basavaraja et al., (2014) in Anjanapura reservoir $\left(25.25^{\circ} \mathrm{C}\right.$ to $\left.30.25^{\circ} \mathrm{C}\right)$. Bharamal and Korgaonkar (2014) while working on Tillari dam $\left(22^{\circ} \mathrm{C}\right.$ to $\left.33^{\circ} \mathrm{C}\right)$. Sreenivasulu et al., (2014) in case of Ramanna tank $\left(25.82^{\circ} \mathrm{C}\right.$ to $31.38^{\circ} \mathrm{C}$ ). Tembhare (2015) while documenting on Kalisarar dam $\left(25^{\circ} \mathrm{C}\right.$ to $\left.32.5^{\circ} \mathrm{C}\right)$. 


\section{Turbidity}

Turbidity is an expression of light scattering and light absorption properties of water and is caused by the presence of suspended matter, such as clay, silt, colloidal organic particles, plankton etc. It is a measure of the interference due to presence of suspended matter to the passage of light. Turbidity due to abiotic colloidal micelles (organic and inorganic) is of paramount importance as these micelle by virtue of their extensive surface area coupled with electrical charge keep nutrient ions adsorbed on their surface rendering equilibrium concentrations of these ions in water phase.

Relatively higher turbidity values observed during monsoon season could be due to the washing of silt, sediments, debris, organic and inorganic particles into the reservoir. It kept on decreased towards summer (as the time progresses), which might be due the settlement of suspended particles due to relatively stagnant water conditions that exists during non-monsoon months.

Water turbidity in upstream was fluctuated between 2.2 NTU during the month of May (summer) and 4.6 NTU in the month of December (monsoon) with a variation of 2.4 NTU and study period Mean (Mean \pm SD) of $3.40 \pm 0.92$ NTU (Table 1). Whereas In downstream water turbidity ranged from 2.4 NTU in the month of May (summer) to 4.9 NTU in the month of December (monsoon) with a variation of $2.5 \mathrm{NTU}$ and study period Mean (Mean $\pm \mathrm{SD}$ ) of $3.63 \pm 0.92 \mathrm{NTU}$ (Table 2).

During the present studies, it fluctuated between 2.2 NTU and 4.9 NTU (Mean \pm SD of $3.51 \pm 0.89 \mathrm{NTU}$ ). Similar studies were made by Pawaiya et al., (2014) documented turbidity values ranging from 0.91 to 3.14 NTU in Harsi reservoir. Mohammad et al.,
(2015) observed turbidity values ranging from 0.5 to $2.2 \mathrm{NTU}$ in Wyra reservoir. Tembhare (2015) recorded turbidity in the range of 1.6 to 3.9 NTU in case of Kalisarar Dam.

\section{Total Dissolved Solids (TDS)}

Total dissolved solid concentration is indicative of the degree of mineralization of water. Dissolved solids in water originate from natural sources and depend up on location, geological nature of the basin, drainage, rainfall, bottom deposits and inflowing water.

Dissolved solids in the upstream station was fluctuated between $179 \mathrm{mg} / \mathrm{L}$ in the month of November (monsoon) and $272 \mathrm{mg} / \mathrm{L}$ in the month of March (summer) with a variation of $\mathrm{mg} 93 \mathrm{mg} / \mathrm{L}$ and a study period Mean (Mean \pm $\mathrm{SD})$ of $219.57 \pm 29.47 \mathrm{mg} / \mathrm{L}$ (Table 1). whereas in downstream total dissolved solids ranged from $158 \mathrm{mg} / \mathrm{L}$ in the month of November (monsoon) to $236 \mathrm{mg} / \mathrm{L}$ in the month of May (summer) with a variation of 78 $\mathrm{mg} / \mathrm{L}$ and study period Mean (Mean $\pm \mathrm{SD}$ ) of $197.43 \pm 23.77 \mathrm{mg} / \mathrm{L}$ (Table 2).

Total dissolved solids of the Kanigiri reservoir fluctuated between $158 \mathrm{mg} / \mathrm{L}$ and $272 \mathrm{mg} / \mathrm{L}$ (Mean \pm SD of $208.50 \pm 28.08 \mathrm{mg} / \mathrm{L}$ ). The observations on TDS clearly indicate that, TDS values were high in summer months followed by winter and monsoon months. The highest values observed during summer season can be attributed to the intense solar radiation and associated high rate of evaporation in comparison to cooler periods during monsoon, which might have diluted the water to certain extent. Based on the observed TDS values these can be considered as medium to high productive reservoirs.

Similar type of observations was made by Lubal et al., (2012) documented TDS values in the range of 178 to $290 \mathrm{mg} / \mathrm{L}$ in Mhaswad 
reservoir. Hussain et al., (2013) reported total dissolved solids ranging from 149 to 211.2 $\mathrm{mg} / \mathrm{L}$ in case of a flood plain reservoir on river Ravi. Pawaiya et al., (2014) observed TDS in the range of 131.25 to $201 \mathrm{mg} / \mathrm{L}$ in case of Harsi reservoir.

\section{pH}

$\mathrm{pH}$ of any aqueous system is suggestive of its acid-base equilibrium achieved by various dissolved compounds in it. $\mathrm{pH}$ of water is a master variable because many reactions that control water quality are $\mathrm{pH}$ dependent.

$\mathrm{pH}$ of water in the upstream station was fluctuated between 7.8 in the months of November and January (monsoon and winter) and 8.5 in the months of April (summer) with a variation of 0.7 and a study period Mean (Mean \pm SD) of 8.11 \pm 0.24 (Table 1). Whereas in downstream water $\mathrm{pH}$ ranged from 7.8 in the month of November (monsoon) to 8.4 in the months of April and May (summer) with a variation of 0.6 and study period Mean (Mean \pm SD) of $8.10 \pm 0.23$ (Table 2).

In Kanigiri reservoir it fluctuated between 7.8 and 8.5 (Mean $\pm \mathrm{SD}$ of $8.11 \pm 0.22 \mathrm{mg} / \mathrm{L}$ ). Maximum values observed during summer might be due to increased photosynthetic activity. The decrease in $\mathrm{pH}$ during monsoon may be due to greater inflow of water, while during winter could be due to decreased photosynthetic activity.

Similar studies were observed by Sugunan and Yadava (1992) reported the average $\mathrm{pH}$ value of Hirakud reservoir as 8.2. Kulshrestha et al., (1992) documented $\mathrm{pH}$ values of 7.2 to 9.5 for Mansarovar reservoir of Bhopal. Thirumathal et al., (2002) noticed $\mathrm{pH}$ in the range of 7.0 to 8.3 in Amaravathy reservoir. Manjare et al., (2010) observed $\mathrm{pH}$ values ranging from 7.3 to 8.8 in Tamdalge tank waters. Murthuzasab et al., (2010) documented $\mathrm{pH}$ values which ranged from 6.54 to 8.6 in case of Hirahalla reservoir. Sangpal et al., (2011) in Ujjani reservoir recorded the $\mathrm{pH}$ in the range of 7.17 to 9.15. Simpi et al., (2011) noticed $\mathrm{pH}$ values in the range of 7.5 to 8.4 in Hosahalli tank waters. Lubal et al., (2012) observed $\mathrm{pH}$ in the range of 7.2 to 8.6 in case of Mhaswad reservoir. Mathavan and Nambirajan (2012) documented $\mathrm{pH}$ values ranging from 6.9 to 8.9 in case of Grand anicut. Meshram (2013) recorded $\mathrm{pH}$ in the range of 7.95 to 8.51 in case of Tandula dam. Muralidharan and Waghode (2014) observed $\mathrm{pH}$ values in the range of 7.4 to 9.1 and 6.9 to 9.0 in case of Tawa and Halali reservoirs respectively.

\section{Dissolved Oxygen (D.O)}

Dissolved oxygen (D.O) is the prime important critical factor in natural waters both as regulator of metabolic processes of biota and as a vital indicator of water quality, ecological and trophic status of a reservoir. This is due to its importance as a respiratory gas, and its significant role in both chemical and biological reactions of an ecosystem.

Dissolved oxygen content of water in the upstream station was fluctuated between 4.8 $\mathrm{mg} / \mathrm{L}$ in the months of November and January (monsoon and winter) and $8.0 \mathrm{mg} / \mathrm{L}$ in the month of April (summer) with a variation of $3.2 \mathrm{mg} / \mathrm{L}$ and a study period Mean (Mean \pm $\mathrm{SD}$ of) $6.12 \pm 1.25 \mathrm{mg} / \mathrm{L}$ (Table 1). whereas in downstream station, dissolved oxygen content ranged from $4.8 \mathrm{mg} / \mathrm{L}$ in the month of November (monsoon) to $8.3 \mathrm{mg} / \mathrm{L}$ in the month of April (summer) with a variation of $3.5 \mathrm{mg} / \mathrm{L}$ and study period Mean (Mean $\pm \mathrm{SD}$ ) of $6.41 \pm 1.34 \mathrm{mg} / \mathrm{L}$ (Table 2).

Dissolved oxygen content of Kanigiri reservoir fluctuated between 4.8 and $8.3 \mathrm{mg} / \mathrm{L}$ (Mean \pm SD of $6.27 \pm 1.26 \mathrm{mg} / \mathrm{L}$ ). From these findings it is seen that, highest dissolved oxygen concentrations were observed during 
summer. These highest values can be attributed to high rate of photosynthetic activity that might have resulted in the liberation of oxygen as a by-product. Lowest oxygen concentrations were observed in the month of November, then oxygen levels slightly increased to December (the month of highest rainfall during the study period) and this might be due to cumulative effect of wind generated turbulence, resultant mixing coupled with rainfall during this period.

Similar findings were observed by Kamble et al., (2011) recorded D.O values ranging from 5.79 to $8.19 \mathrm{mg} / \mathrm{L}$ in waters from Bhandaradara reservoir. Mathavan and Nambirajan (2012) documented D.O values of waters from Grand anicut as ranging from 4.7 to $5.8 \mathrm{mg} / \mathrm{L}$. Bhadja and Vaghela (2013) observed D.O values in the range of 6.12 to $7.05 \mathrm{mg} / \mathrm{L}, 5.99$ to $6.26 \mathrm{mg} / \mathrm{L}$ and 6.62 to 7.09 $\mathrm{mg} / \mathrm{L}$ in case of Aji, Nyari and Lalpari reservoirs of Sourashtra respectively. Idowu et al., (2013) in Ado-Ekiti reservoir of Nigeria noticed D.O values ranging from 4.08 to 8.98 mg/L. Meshram (2013) documented D.O values ranging from 5.99 to $7.09 \mathrm{mg} / \mathrm{L}$ in case of Tandula dam. Basavaraja et al., recorded (2014) DO values in the range of 5.72 to 8.28 $\mathrm{mg} / \mathrm{L}$ in Anjanapura reservoir. Sreenivasulu et al., (2014) noticed D.O values ranging from 4.55 to $7.06 \mathrm{mg} / \mathrm{L}$ in the waters of Ramanna tank. Mohammad et al., (2015) observed D.O in the range of 4.1 to $6.5 \mathrm{mg} / \mathrm{L}$ in case of Wyra reservoir.

\section{Carbon Dioxide $\left(\mathrm{CO}_{2}\right)$}

Carbon dioxide is particularly influential in regulating $\mathrm{pH}$. Organic decomposition, respiration, photosynthesis, diffusion and runoff etc. brings about changes in the carbon dioxide concentrations of water. It is highly soluble in natural waters but is a minor constituent of the atmosphere and remains present in equilibrium concentration by giving an acidic reaction in water. Its absence or low concentrations recorded in most of the times may be due to the alkaline nature of the water in both the reservoirs.

$\mathrm{CO}_{2}$ content of water in the upstream station was fluctuated between $0.0 \mathrm{mg} / \mathrm{L}$ in the months of March and April (summer) and 6.0 $\mathrm{mg} / \mathrm{L}$ in the month of December (monsoon) with a variation of $6.0 \mathrm{mg} / \mathrm{L}$ and a study period Mean (Mean \pm SD) of $2.07 \pm 1.77$ $\mathrm{mg} / \mathrm{L}$ (Table 1). Whereas in downstream $\mathrm{CO}_{2}$ levels of water ranged from $0.0 \mathrm{mg} / \mathrm{L}$ in the months of February, March, April, May (winter and summer) to $6.0 \mathrm{mg} / \mathrm{L}$ in the months of January (winter) with a variation of $6.0 \mathrm{mg} / \mathrm{L}$ and study period Mean (Mean $\pm \mathrm{SD}$ ) of $1.57 \pm 1.91 \mathrm{mg} / \mathrm{L}$ (Table 2).

Free $\mathrm{CO}_{2}$ content of Kanigiri reservoir varied from $0 \mathrm{mg} / \mathrm{L}$ to $6 \mathrm{mg} / \mathrm{L}$ (Mean \pm SD of $1.82 \pm$ $1.79 \mathrm{mg} / \mathrm{L})$ More or less higher values observed during monsoon and winter seasons can be attributed to decreased photosynthetic rates during these seasons besides decomposition of allochthonous organic matter that have entered in to the reservoir through runoff.

Similar type of observations was made by Lianthuamluaia et al., (2013) recorded $\mathrm{CO}_{2}$ levels ranging from 0 to $8.93 \mathrm{mg} / \mathrm{L}$ in case of Savitri reservoir. Saxena and Saksena (2012) noticed free $\mathrm{CO}_{2}$ in the range of 0 to 9.3 in Raipur reservoir.

\section{Chlorides}

Chlorides occur naturally in waters. Discharge of sewage contributes to chlorides there by their concentration serves as an indicator of pollution by sewage.

Chloride concentration of water in the upstream station was fluctuated between 88 $\mathrm{mg} / \mathrm{L}$ in the month of January (winter) and 
$132 \mathrm{mg} / \mathrm{L}$ in the month of April (summer) with a variation of $44 \mathrm{mg} / \mathrm{L}$ and a study period Mean (Mean \pm SD) of $113.64 \pm 16.44 \mathrm{mg} / \mathrm{L}$ (Table 1). whereas in downstream station, chlorides ranged from $68 \mathrm{mg} / \mathrm{L}$ in the month of February (winter) to $126 \mathrm{mg} / \mathrm{L}$ in the month of April (summer) with a variation of $58 \mathrm{mg} / \mathrm{L}$ and study period Mean (Mean \pm SD) of $101.86 \pm 18.12 \mathrm{mg} / \mathrm{L}$ (Table 2).

The concentration of chlorides in the Kanigiri reservoir fluctuated between $68 \mathrm{mg} / \mathrm{L}$ and 132 $\mathrm{mg} / \mathrm{L}($ Mean $\pm \mathrm{SD}$ of $107.75 \pm 17.68 \mathrm{mg} / \mathrm{L})$. Higher values of chlorides were observed during summer and monsoon samplings compared to winter. Higher values of summer could be attributed to high rate of evaporation, which might have resulted in increase in their concentration, while high values observed in monsoon samplings might be due to the entry of runoff including sewage from the catchment area.

Similar studies was made by Pisca et al., (2000) noticed chlorides in the range of 33.25 to $97.93 \mathrm{mg} / \mathrm{L}$ from the waters of Ibhrahim reservoir. Jadoon et al., (2013) expressed chloride levels ranging from 57.5 to 100.1 $\mathrm{mg} / \mathrm{L}$ in case of Darbandikhan reservoir, Iraq. Mohammad et al., (2015) reported chlorides in the range of 80 to $240 \mathrm{mg} / \mathrm{L}$ in case of Wyra reservoir.

\section{Biochemical Oxygen Demand (BOD)}

BOD gives a quantitative measure of biodegradable carbonaceous organic matter present in the water. It is the measure of the extent of pollution in the water body, its value provides an information regarding quality of water and helps in deciding the suitability of water for consumption and other purposes. The untreated discharge of municipal and domestic waste in to water bodies increases the amount of organic matter. BOD of water in the upstream station was fluctuated between
$4.3 \mathrm{mg} / \mathrm{L}$ in the month of March (summer) and $8.2 \mathrm{mg} / \mathrm{L}$ in the months of November (monsoon) with a variation of $3.9 \mathrm{mg} / \mathrm{L}$ and a study period Mean (Mean \pm SD) of $5.9 \pm 1.24$ $\mathrm{mg} / \mathrm{L}$ (Table 1). Whereas in downstream station, BOD of water ranged from $3.8 \mathrm{mg} / \mathrm{L}$ in the month of March (summer) to $7.8 \mathrm{mg} / \mathrm{L}$ in the month of November (monsoon) with a variation of $4 \mathrm{mg} / \mathrm{L}$ and study period Mean (Mean $\pm \mathrm{SD}$ ) of $5.4 \pm 1.26 \mathrm{mg} / \mathrm{L}$ (Table 2).

BOD of water from Kanigiri reservoir varied between $3.8 \mathrm{mg} / \mathrm{L}$ and $8.2 \mathrm{mg} / \mathrm{L}$ (Mean $\pm \mathrm{SD}$ of $5.65 \pm 1.23 \mathrm{mg} / \mathrm{L})$. More or less higher BOD values were observed in monsoon and winter seasons compared to summer season. To certain extent this can be ascribed to entry of allochthonous organic matter through runoff during rainy season, which up on being subjected to aerobic degradation might have resulted in high BOD values.

Similar results were found by Bhadja and Vaghela (2013) documented BOD values ranging from 3.95 to $5.14 \mathrm{mg} / \mathrm{L}$ in case of Lalpari reservoir. Muralidharan and Waghode (2014) recorded BOD values in the range of 2.65 to $6.94 \mathrm{mg} / \mathrm{L}$ and 3.2 to $6.8 \mathrm{mg} / \mathrm{L}$ in case of Tawa and Halali reservoirs respectively. Gayathri et al., (2015) noticed BOD levels ranging from 5.51 to $6.2 \mathrm{mg} / \mathrm{L}$ in case of Manchanabele reservoir.

\section{Total ammonia}

Ammonia in higher concentrations is harmful to fish and other aquatic life. The toxicity of ammonia increases with increase in $\mathrm{pH}$, as at higher $\mathrm{pH}$, most of the ammonia remains in its gaseous (unionized) form.

Total ammonia levels of water in the upstream station was fluctuated between $0.02 \mathrm{mg} / \mathrm{L}$ in the month of March (summer) and $0.35 \mathrm{mg} / \mathrm{L}$ in the month of November (monsoon) with a variation of $0.33 \mathrm{mg} / \mathrm{L}$ and a study period 
Mean (Mean \pm SD) of $0.12 \pm 0.10 \mathrm{mg} / \mathrm{L}$ (Table 1). whereas in downstream station, ammonia concentrations ranged from 0.03 $\mathrm{mg} / \mathrm{L}$ in the months of March and April (summer) to $0.25 \mathrm{mg} / \mathrm{L}$ in the month of November (monsoon) with a variation of 0.22 $\mathrm{mg} / \mathrm{L}$ and study period Mean (Mean $\pm \mathrm{SD}$ ) of $0.09 \pm 0.07 \mathrm{mg} / \mathrm{L}$ (Table 2).

Ammonia content of the Kanigiri reservoir varied between $0.02 \mathrm{mg} / \mathrm{L}$ and $0.35 \mathrm{mg} / \mathrm{L}$ (Mean \pm SD of $0.11 \pm 0.09 \mathrm{mg} / \mathrm{L}$ ). In most of the instances, higher ammonia content observed during monsoon and subsequent winter seasons could be due to the decomposition of organic matter that has entered into these reservoirs through rain fall during monsoon season from the catchment area.

Similar type of observations was made by Lianthuamluaia et al., (2013) recorded ammonia levels ranging from 0.026 to 0.18 $\mathrm{mg} / \mathrm{L}$ in case of Savitri reservoir. Pawaiya et al., (2014) reported ammonia concentrations in the range of 0.39 to $0.84 \mathrm{mg} / \mathrm{L}$ from Harsi reservoir. Pulugandi (2014) noticed ammonia concentrations ranging from 0.49 to $1.08 \mathrm{mg} / \mathrm{L}$ from the waters of Vembakottai reservoir.

\section{Total alkalinity}

Alkalinity of water is its capacity to neutralize acids. Weathering of rocks is the potential source of it and it imparts buffering capacity to water, there by helps in stabilizing the $\mathrm{pH}$ of water. Though incidence of nitrates, borates, silicates contributes to alkalinity, it is primarily due to the presence of carbonates, bicarbonates and hydroxyl ions in free state in water. The influence of photosynthesis on $\mathrm{pH}$ is greater in low alkalinity waters because of their low buffering capacity.

Total alkalinity in the upstream station was fluctuated between $124 \mathrm{mg} / \mathrm{L}$ in the month of February (winter) and $184 \mathrm{mg} / \mathrm{L}$ in the month of May (summer) with a variation of $60 \mathrm{mg} / \mathrm{L}$ and a study period Mean (Mean \pm SD) of $158.64 \pm 18.06 \mathrm{mg} / \mathrm{L}$ (Table 1). Whereas In downstream station, alkalinity of water ranged from $128 \mathrm{mg} / \mathrm{L}$ in the month of November (monsoon) to $210 \mathrm{mg} / \mathrm{L}$ in the month of March (summer) with a variation of $82 \mathrm{mg} / \mathrm{L}$ and study period Mean (Mean \pm SD) of $159.5 \pm$ $24.31 \mathrm{mg} / \mathrm{L}$ (Table 2).

During the present investigation, alkalinity values fluctuated between $124 \mathrm{mg} / \mathrm{L}$ and 210 $\mathrm{mg} / \mathrm{L}($ Mean $\pm \mathrm{SD}$ of $159.07 \pm 20.64 \mathrm{mg} / \mathrm{L})$. From the observed alkalinity values, waters from both the reservoirs can be considered as moderate alkalinity waters. The observed summer higher values compared to monsoon and winter seasons might have resulted from the effect of $\mathrm{pH}$ on the relative proportions of different forms $\left(\mathrm{CO}_{2}, \mathrm{HCO}_{3}{ }^{-}\right.$and $\left.\mathrm{CO}_{3}{ }^{-2}\right)$ of inorganic carbon. Slightly higher values of alkalinity were observed during summer as was observed in case of $\mathrm{pH}$.

Similar type of observations was made by Manjare et al., (2010) noticed alkalinity in the range of 121.25 to $200 \mathrm{mg} / \mathrm{L}$ in Tamdalge tank waters. Simpi et al., (2011) observed total alkalinity values in the range of 110 to 165 $\mathrm{mg} / \mathrm{L}$ in case of Hosahalli tank waters. Lubal et al., (2012) documented alkalinity in the range of 182 to $270 \mathrm{mg} / \mathrm{L}$ from Mhaswad reservoir. Hussain et al., (2013) recorded total alkalinity in the range of 100 to $119 \mathrm{mg} / \mathrm{L}$ in a flood plain reservoir on river Ravi. Pulugandi (2014) reported alkalinity values ranging from 144.3 to $582 \mathrm{mg} / \mathrm{L}$ in case of Vembakottai reservoir, Tamil Nadu. Sreenivasulu et al., (2014) noticed total alkalinity ranging from 284.5 to $399 \mathrm{mg} / \mathrm{L}$ in case of Ramanna tank waters.

\section{Total hardness}

The principle ions causing hardness in water are the divalent cations, especially calcium and magnesium in case of surface waters. 
Dissolution of limestone is the primary source of these ions in water.

Total hardness of water in the upstream station was fluctuated between $152 \mathrm{mg} / \mathrm{L}$ in the month of May (summer) and $266 \mathrm{mg} / \mathrm{L}$ in the month of December (monsoon) with a variation of $114 \mathrm{mg} / \mathrm{L}$ and a study period Mean (Mean \pm SD) of $218.07 \pm 39.34 \mathrm{mg} / \mathrm{L}$ (Table 1). Whereas in downstream station, hardness levels ranged from $144 \mathrm{mg} / \mathrm{L}$ in the month of May (summer) to $258 \mathrm{mg} / \mathrm{L}$ in the month of December (monsoon) with a variation of $114 \mathrm{mg} / \mathrm{L}$ and study period Mean (Mean \pm SD) of $200.43 \pm 35.77 \mathrm{mg} / \mathrm{L}$ (Table 2).

During the present investigation, hardness values fluctuated between $144 \mathrm{mg} / \mathrm{L}$ and 266 $\mathrm{mg} / \mathrm{L}$ (Mean $\pm \mathrm{SD}$ of $209.25 \pm 37.29 \mathrm{mg} / \mathrm{L}$ ). Higher values of hardness observed during monsoon and winter seasons are probably due to the addition of dissolved minerals from sedimentary rocks, large quantities of sewage and detergents in to the reservoir through surface runoff from surrounding watershed area.

Similar observations were found by Thirupathaiah et al., (2012) recorded hardness values ranging from 159 to $188 \mathrm{mg} / \mathrm{L}$ in case of Lower Manair reservoir. Bhadja and Vaghela (2013) reported total hardness values in the range of 221 to $258 \mathrm{mg} / \mathrm{L}, 231.5$ to 251 $\mathrm{mg} / \mathrm{L}$ and 243.5 to $265 \mathrm{mg} / \mathrm{L}$ from Aji, Nyari and Lalpari reservoirs of Sourashtra respectively. Hussain et al., (2013) documented total hardness values in the range of 120 to $160 \mathrm{mg} / \mathrm{L}$ in case of a flood plain reservoir on river Ravi. Meshram (2013) noticed total hardness ranging from 221 to 265 $\mathrm{mg} / \mathrm{L}$ in Tandula dam waters. Sreenivasulu et al., (2014) reported total hardness values ranging from 119 to $165 \mathrm{mg} / \mathrm{L}$ in Ramanna tank waters. In Harsi reservoir, Pawaiya et al., (2014) noticed total hardness in the range of
63 to $103 \mathrm{mg} / \mathrm{L}$. Gayathri et al., (2015) observed hardness values ranging from 174 to $192 \mathrm{mg} / \mathrm{L}$ in the waters of Manchanabele reservoir. Mohammad et al., (2015) documented hardness values in the range of 180 to $240 \mathrm{mg} / \mathrm{L}$ from waters of Wyra reservoir.

\section{Statistical analysis}

The degree of relationship that existed among the parameters under the study were represented station wise in-terms of Correlation co-efficient at $99 \%$ and $95 \%$ level of significance. (Table 3 and 4 representing stations $\mathrm{K} 1$ and $\mathrm{K} 2$ respectively). From the correlation co- efficient values obtained based on the relationship that existed among different physico- chemical parameters of the reservoir stations under study, Highly significant (at 99\% level) positive correlation were observed among air temperature and water temperature; air temperature and TDS; air temperature and $\mathrm{pH}$; air temperature and D.O. Same was observed between water temperature and $\mathrm{pH}$; water temperature and TDS; water temperature and D.O. Highly significant (at 99\% level) negative correlation were observed among air temperature and turbidity; turbidity and $\mathrm{pH}$; turbidity and D.O; turbidity and TDS.

It is concluded that the concentrations of TDS estimated for the waters of both the stations fell within tolerable limits for drinking water as they did not exceed 500 ppm (EPA, 1976; WHO, 1984: WHO, 2004; BIS, 1991; BIS, 2012) thereby they are suitable as a source of drinking water supply. With mean TDS values of $219.57 \mathrm{mg} / \mathrm{L}$ (Upstream) and $197.43 \mathrm{mg} / \mathrm{L}$ (Upstream), it is evident that, they can support good fish production, as per Jhingran and Sugunan (1990) who noticed TDS values of more than $200 \mathrm{ppm}$ in case of high productive reservoirs. 
Table.1 Kanigiri reservoir upstream

\begin{tabular}{|c|c|c|c|c|c|c|c|c|c|c|c|c|c|}
\hline & & A.T & W. T & $\mathrm{T}$ & TDS & $\mathrm{pH}$ & D.O & $\mathrm{CO}_{2}$ & $\mathrm{Cl}$ & BOD & NH3 & $\mathrm{TA}$ & T.H \\
\hline \multirow{2}{*}{ Nov. } & $1^{\mathrm{st}} \mathrm{F}$ & 27.8 & 27.6 & 4.4 & 179 & 7.9 & 4.4 & 1 & 145 & 8.8 & 0.39 & 178 & 212 \\
\hline & $2^{\text {nd }} F$ & 28.0 & 27.8 & 4.3 & 184 & 7.8 & 4.2 & 4 & 124 & 9.4 & 0.3 & 164 & 240 \\
\hline \multirow[t]{2}{*}{ Dec. } & $1^{\mathrm{st}} \mathrm{F}$ & 27.9 & 27.6 & 4.6 & 186 & 8.1 & 4.8 & 8 & 139 & 8.4 & 0.27 & 162 & 240 \\
\hline & $2^{\text {nd }} F$ & 28.2 & 28.0 & 4.2 & 204 & 7.9 & 4.9 & 6 & 122 & 9 & 0.25 & 148 & 238 \\
\hline \multirow[t]{2}{*}{ Jan. } & $1^{\mathrm{st}} \mathrm{F}$ & 28.4 & 28.2 & 4.3 & 202 & 7.8 & 4.9 & 6 & 128 & 6.4 & 0.18 & 172 & 252 \\
\hline & $2^{\text {nd }} F$ & 28.6 & 28.5 & 4.2 & 216 & 8.0 & 5 & 8 & 112 & 5.6 & 0.14 & 186 & 246 \\
\hline \multirow[t]{2}{*}{ Feb. } & $1^{\mathrm{st}} \mathrm{F}$ & 28.2 & 28.0 & 3.3 & 214 & 8.1 & 5 & 4 & 132 & 6 & 0.1 & 168 & 210 \\
\hline & $2^{\text {nd }} F$ & 27.8 & 27.5 & 3.6 & 196 & 7.9 & 5.4 & 2 & 126 & 6.4 & 0.08 & 174 & 252 \\
\hline \multirow[t]{2}{*}{ Mar. } & $1^{\mathrm{st}} \mathrm{F}$ & 31.4 & 31.2 & 2.3 & 272 & 8.3 & 6 & 2 & 165 & 4.8 & 0.05 & 184 & 226 \\
\hline & $2^{\text {nd }} F$ & 31.8 & 31.4 & 2.7 & 248 & 8.2 & 6.2 & 0 & 154 & 5.9 & 0.08 & 232 & 194 \\
\hline \multirow[t]{2}{*}{ Apr. } & $1^{\mathrm{st}} \mathrm{F}$ & 31.7 & 31.5 & 2.6 & 245 & 8.5 & 6.8 & 1 & 204 & 4.8 & 0.03 & 192 & 192 \\
\hline & $2^{\text {nd }} F$ & 32.0 & 32.0 & 2.3 & 232 & 8.3 & 7 & 0 & 168 & 5.4 & 0.02 & 212 & 176 \\
\hline \multirow[t]{2}{*}{ May } & $1^{\mathrm{st}} \mathrm{F}$ & 32.4 & 32.3 & 2.2 & 256 & 8.4 & 7 & 2 & 192 & 5.4 & 0.06 & 186 & 186 \\
\hline & $2^{\text {nd }} F$ & 32.4 & 32.2 & 2.6 & 240 & 8.4 & 7.2 & 2 & 180 & 5 & 0.08 & 204 & 202 \\
\hline
\end{tabular}

A.T-Air Temperature, W.T-Water Temperature, T-Turbidity, TDS-Total Dissolved Solids, D.O-Dissolved oxygen, CO ${ }_{2}$-Carbon dioxide, Cl-Chlorides, BODBiochemical Oxygen Demand, $\mathrm{NH}_{3}$-Toatl ammonia, T.A-Total alkalinity, T.H-Total hardness. 


\section{Int.J.Curr.Microbiol.App.Sci (2018) 7(8): 979-996}

Table.2 Kanigiri reservoir downstream

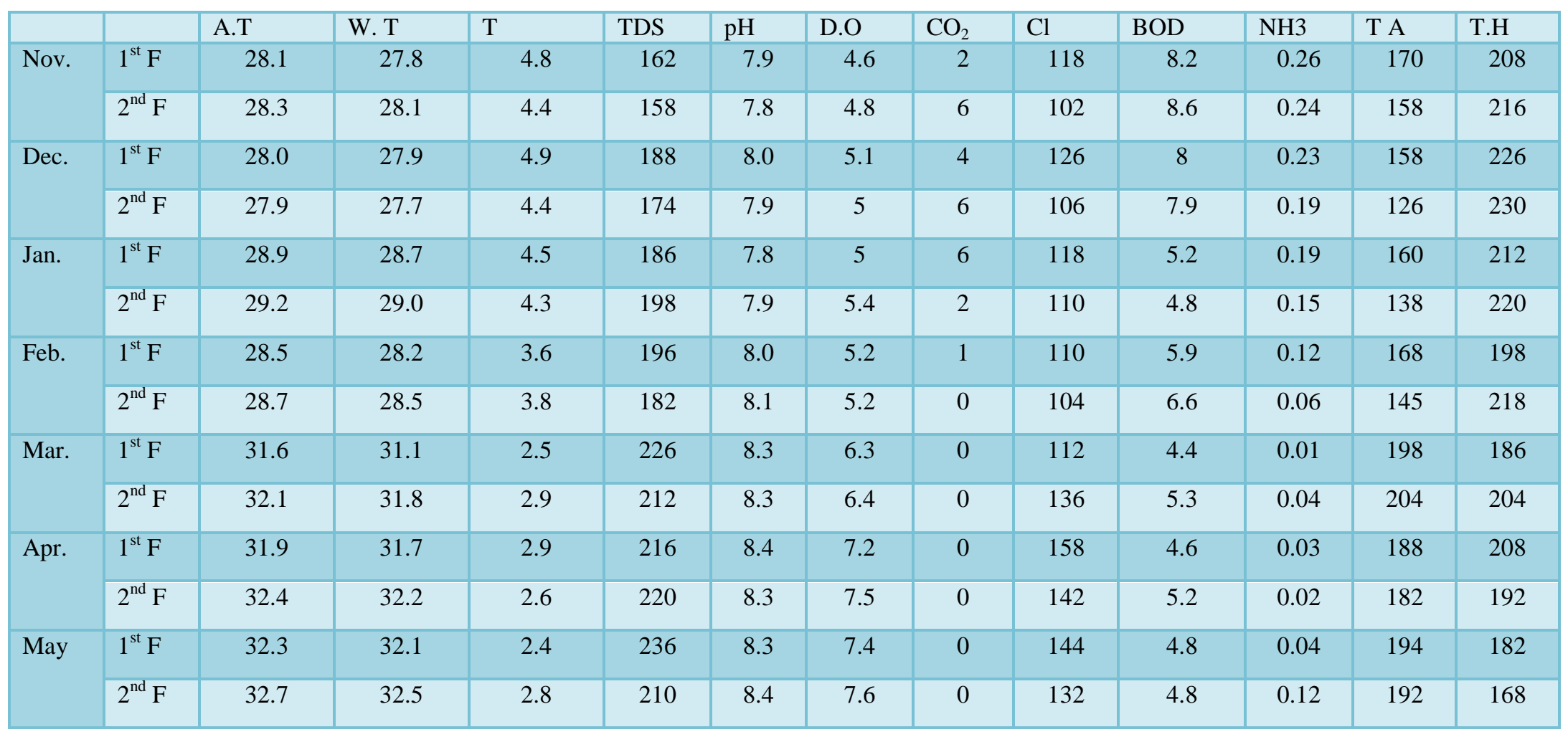

A.T-Air Temperature, W.T-Water Temperature, T-Turbidity, TDS-Total Dissolved Solids, D.O-Dissolved oxygen, CO ${ }_{2}$-Carbon dioxide, Cl-Chlorides, BODBiochemical Oxygen Demand, $\mathrm{NH}_{3}$-Toatl ammonia, T.A-Total alkalinity, T.H-Total hardness. 
Table.3 Correlation Co-efficient values observed between different physico-chemical parameters of water at Station K1

\begin{tabular}{|c|c|c|c|c|c|c|c|c|c|c|c|c|}
\hline & A.T & W. T & $\mathrm{T}$ & TDS & $\mathrm{pH}$ & D.O & $\mathrm{CO}_{2}$ & $\mathrm{Cl}$ & BOD & NH3 & T A & T.H \\
\hline A.T & 1.000 & $.999^{* *}$ & $-.918^{* *}$ & $.892^{* *}$ & $.888^{* *}$ & $.920^{* * *}$ & $-.561^{*}$ & $.544^{*}$ & $-.786^{* *}$ & -0.488 & $.616^{*}$ & $-.919^{* *}$ \\
\hline W. T & & 1.000 & $-.917^{* *}$ & $.889^{* *}$ & $.887^{* *}$ & $.924^{* *}$ & $-.554^{*}$ & $.538^{*}$ & $-.787^{* *}$ & -0.480 & $.606^{*}$ & $-.914^{* *}$ \\
\hline $\mathrm{T}$ & & & 1.000 & $-.907^{* *}$ & $-.860^{* *}$ & $-.904^{* *}$ & $.683^{* *}$ & -0.366 & $.824^{* *}$ & $.618^{*}$ & -0.403 & $.895^{* *}$ \\
\hline TDS & & & & 1.000 & $.825^{* *}$ & $.759^{* *}$ & -0.447 & 0.272 & $-.903^{* *}$ & $-.676^{* *}$ & 0.427 & $-.785^{* *}$ \\
\hline $\mathrm{pH}$ & & & & & 1.000 & $.916^{* *}$ & -0.494 & $.552^{*}$ & $-.771^{* *}$ & -0.486 & 0.504 & $-.866^{* *}$ \\
\hline D.O & & & & & & 1.000 & $-.620^{*}$ & $.556^{*}$ & $-.738^{* *}$ & -0.457 & $.537^{*}$ & $-.914^{* *}$ \\
\hline $\mathrm{CO}_{2}$ & & & & & & & 1.000 & -0.471 & 0.242 & 0.226 & -0.057 & $.639^{*}$ \\
\hline $\mathrm{Cl}$ & & & & & & & & 1.000 & -0.041 & 0.308 & $.572^{*}$ & -0.487 \\
\hline BOD & & & & & & & & & 1.000 & $.831^{* *}$ & -0.400 & $.709^{* *}$ \\
\hline NH3 & & & & & & & & & & 1.000 & -0.159 & 0.510 \\
\hline $\mathrm{TA}$ & & & & & & & & & & & 1.000 & $-.634^{*}$ \\
\hline T.h & & & & & & & & & & & & 1.000 \\
\hline
\end{tabular}

A.T-Air Temperature, W.T-Water Temperature, T-Turbidity, TDS-Total Dissolved Solids, D.O-Dissolved oxygen, $\mathrm{CO}_{2}$-Carbon dioxide, Cl-Chlorides, BODBiochemical Oxygen Demand, $\mathrm{NH}_{3}$-Toatl ammonia, T.A-Total alkalinity, T.H-Total hardness. 
Table.4 Correlation Co-efficient values observed between different physico-chemical parameters of water at Station K2

\begin{tabular}{|c|c|c|c|c|c|c|c|c|c|c|c|c|}
\hline & A. $\mathrm{T}$ & W. T & $\mathrm{T}$ & TDS & $\mathrm{pH}$ & D.O & $\mathrm{CO}_{2}$ & $\mathrm{Cl}$ & BOD & NH3 & T A & T.H \\
\hline A. $T$ & 1.000 & $.999^{* *}$ & $-.926^{* *}$ & $.870^{* *}$ & $.905^{* *}$ & $.956^{* *}$ & $-.655^{*}$ & $.660^{*}$ & $-.725^{* *}$ & $-.661^{*}$ & $.734^{* *}$ & $-.788^{* *}$ \\
\hline W. T & & 1.000 & $-.916^{* *}$ & $.866^{* *}$ & $.904^{* *}$ & $.960^{* *}$ & $-.647^{*}$ & $.666^{* *}$ & $-.716^{* * *}$ & $-.654^{*}$ & $.726^{* *}$ & $-.779^{* *}$ \\
\hline $\mathrm{T}$ & & & 1.000 & $-.885^{* *}$ & $-.894^{* *}$ & $-.894^{* *}$ & $.738^{* *}$ & -0.480 & $.763^{* *}$ & $.773^{* *}$ & $-.699^{* *}$ & $.896^{* *}$ \\
\hline TDS & & & & 1.000 & $.819^{* *}$ & $.833^{* *}$ & $-.663^{* *}$ & 0.495 & $-.851^{* *}$ & $-.800^{* *}$ & $.729^{* *}$ & $-.834^{* *}$ \\
\hline $\mathrm{pH}$ & & & & & 1.000 & $.954^{* *}$ & $-.751^{* *}$ & $.667^{* *}$ & $-.652^{*}$ & $-.685^{* *}$ & $.677^{* *}$ & $-.815^{* *}$ \\
\hline D.O & & & & & & 1.000 & $-.676^{* *}$ & $.698^{* *}$ & $-.653^{*}$ & $-.654^{*}$ & $.661^{* *}$ & $-.793^{* *}$ \\
\hline $\mathrm{CO}_{2}$ & & & & & & & 1.000 & -0.389 & 0.412 & $.581^{*}$ & $-.591^{*}$ & $.832^{* *}$ \\
\hline $\mathrm{Cl}$ & & & & & & & & 1.000 & -0.195 & -0.034 & 0.472 & -0.319 \\
\hline BOD & & & & & & & & & 1.000 & $.883^{* *}$ & $-.590^{*}$ & $.634^{*}$ \\
\hline $\mathrm{NH} 3$ & & & & & & & & & & 1.000 & $-.667^{* *}$ & $.791^{* *}$ \\
\hline $\mathrm{TA}$ & & & & & & & & & & & 1.000 & $-.662^{* *}$ \\
\hline T.H & & & & & & & & & & & & 1.000 \\
\hline
\end{tabular}

A.T-Air Temperature, W.T-Water Temperature, T-Turbidity, TDS-Total Dissolved Solids, D.O-Dissolved oxygen, $\mathrm{CO}_{2}$-Carbon dioxide, Cl-Chlorides, BODBiochemical Oxygen Demand, $\mathrm{NH}_{3}$-Toatl ammonia, T.A-Total alkalinity, T.H-Total hardness. 
Fig.1 Map showing the location of sampling stations

\begin{tabular}{|c|c|c|c|}
\hline & Stations & Latitude & Longitude \\
\hline 1 & Kanigiri Upstream (K1) & $\mathrm{N} 14^{0} 32.877^{\prime}$ & E $79^{0} 51.616^{\prime}$ \\
\hline 2 & Kanigiri Downstream (K2) & $\mathrm{N} 14^{0} 32.711^{\prime}$ & E $79^{0} 51.530^{\prime}$ \\
\hline
\end{tabular}

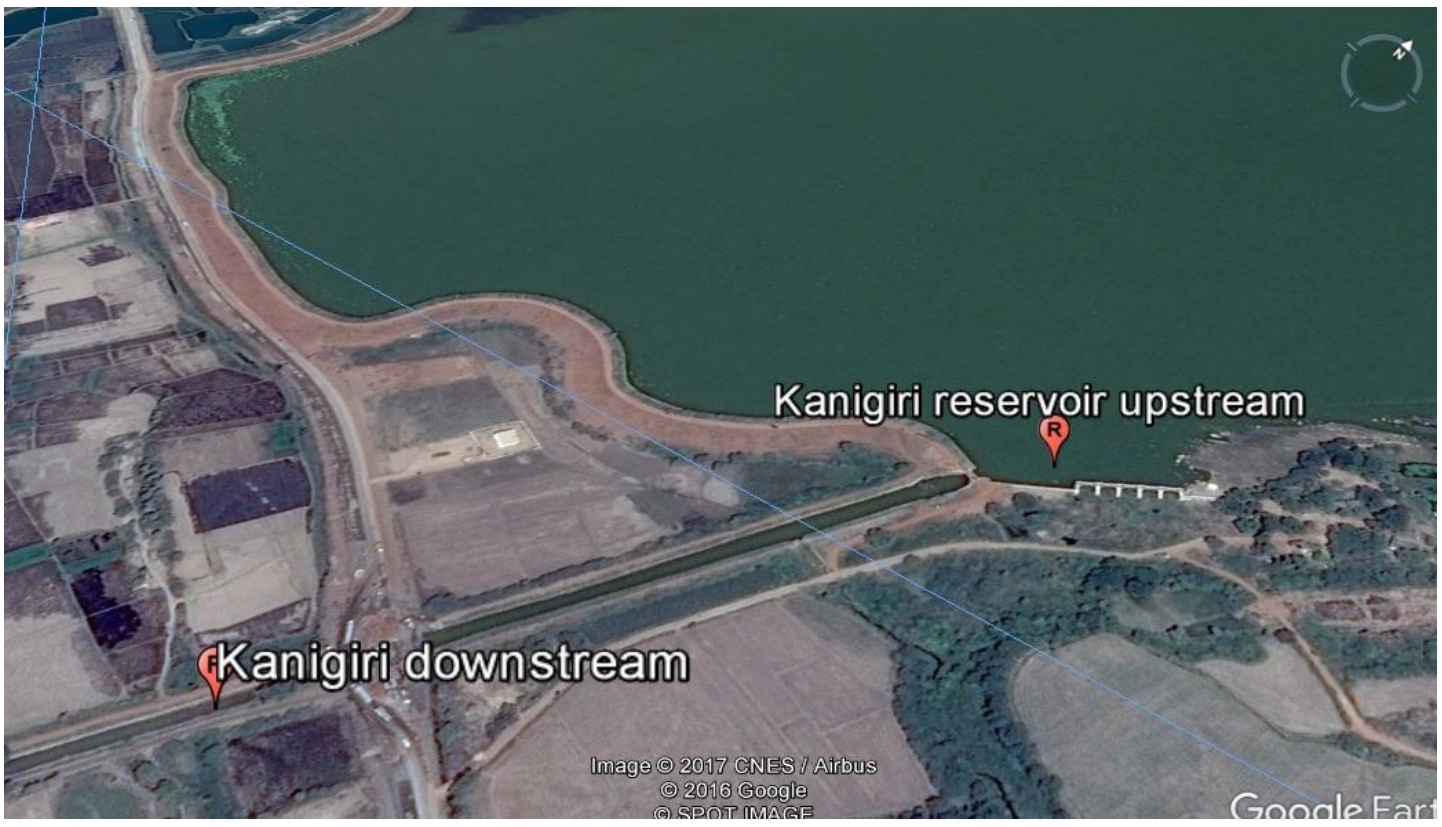

Relatively higher turbidity values observed during monsoon season could be due to the washing of silt, sediments, debris, organic and inorganic particles into the reservoir. It kept on decreased towards summer (as the time progresses), which might be due the settlement of suspended particles due to relatively stagnant water conditions that exists during non-monsoon months.

\section{References}

APHA (American Public Health Association). Standard methods for the examination of water and waste water $\left(21^{\text {th }} e d\right.$. $)$. American Public Health Association, Washington, DC; 2005.

Basavaraja, D., Narayana, J., Kiran, B.R.. and Puttaiah, E.T. Fish diversity and abundance in relation to water quality of Anjanapura reservoir, Karnataka, India. Int. J. Curr. Microbiol. Appli. Sci., 2014; 3(3): 747-757.

Bhadja, P. and Vaghela, A.K. Assessment of Physico-chemical parameters and Water quality Index of Lalpari reservoir. Int. J. Plant Anim. Environ. Sci., 2013; 3(3): 89-95.

Bhadja, P. and Vaghela, A.K. Assessment of Physico-chemical parameters and Water quality Index of Lalpari reservoir. Int. J. Plant Anim. Environ. Sci., 2013; 3(3): 89-95.

Bureau of Indian Standards (BIS), "IS: 10500:1991", Drinking waterSpecifications (First revision), Drinking water Sectional Committee, India. 
Bureau of Indian Standards (BIS), "IS: 10500:2012", Drinking waterSpecifications (Second revision), Drinking water Sectional Committee, FAD25, May, 2012, India, pp.1-11.

Gayathri, S., Latha, N. and Mohan, M.R. Water quality status of Manchanabele reservoir: Bangalore west region, Karnataka, India. Int. J. Innovative. Sci. Eng. Tech., 2015; 2(12): 364-372.

Grag, R.k., Rao, R. J., Uchchariya, D., Shuklal, G. and Saksena, D.N. Seasonal variations in water quality and major threats to Ramsagar reservoir, India. African Journal of Environmental Science and Technology. 2010; 4(2) 61-76.

Hussain, A., Sulehria, A.Q.K., Ejaz, M. and Maqbool, A. Monthly variations in physico-chemical parameters of a flood plain reservoir on river Ravi near Balloki Head waters (Pakisthan). Biologia, 2013; 59(2): 371-377.

ICOLD, 1998. Position paper on dams and environment at http://genepi.louis Jean.com/cigb/chartean.html.

Idowu, E.O., Ugwumba, A.A.A., Edward, J.B. and Oso, J.A., 2013. Study of the seasonal variations in the physicochemical parameters of a Tropical reservoir. Gree. J. Physic. Sci., 3(4): $142-148$.

Jadoon, S., Munir, S. and Abdulhamid, A.M. Analyzing water quality in Darbandikhan reservoir, Kurdistan region, Iraq. Int. J. Sci. Res., 2015; 4(12): 761-770.

Kamble, P.N., Gaikwad, V.B. and Kuchekar, S.R. Monitoring of physicho-chemical parameters and quality assessment of water from Bhandaradara reservoir. Der Chemica Sinica, 2011; 2(4): 229234.

Kulshreshtha, S.K., George, M.P., Saxena, R., Johri, M. and Shrivastava, M. Seasonal variations in the limnochemical characteristics of Manasa Sarovar reservoir of Bhopal. In Mishra, S.R. and Saksena, D.N. (eds.). Aqua. Ecol., Ashish Publishing House, New Delhi, 1992; 275-292.

Lianthuuamluaia, Langde, A.T., Purushothaman, C.S., Deshmukhe, G. and Ramteke, K.K. Assessment of seasonal variations of water quality parameters of Savitri reservoir, Poladpur, Raigad, Maharashtra. The Bioscan, 2013; 8(4): 1337-1342.

Lubal, M.J., Sutar, A.U. and Pawar, K.W. Studies on physico-chemical aspects of Mhaswad water reservoir of Satara district (Maharashtra) India. Int. J. Plant anim. Environ. Sci., 2012; 2(3): 12-15.

Manjare, S.A., Vhanalakar, A. and Muley, D.V. Analysis of water quality using physico-chemical parameters of Tamdalge tank in Kolhapur Dist., Maharashtra. Inter. J. Adv. Biotech. Res., 2010; 1(2): 115-119.

Mathavan, N. and Nambirajan, P. Studies on the physico-chemical parameters of Grant anicut (Kallani), Thanjavur district, Tamil Nadu, India. Int. J. Phar. Biol. Sci., 2012; 2(4): 32-40.

Meshram, L. Hydrobiological studies on fresh water reservoir of Tandula dam of district Balod (C.G.), India. Int. J. Sci. Res., 2013; 4(9): 1866-1869.

Mohammad, M.J., Krishna, P.V., Lamma, O.A. and Khan, S. Analysis of Water Quality using Limnological Studies of Wyra Reservoir, Khammam District, Telangana, India. Int. J. Curr. Microbiol. App.Sci., 2015; 4(2): 880895.

Muralidhran, L. and Waghode, S. Studies on Physico-chemical characteristics of Tawa ana Halali reservoirs of Bhopal, India. Int. J. Current. Sci., 2014; 11: 70-83.

Muralidhran, L. and Waghode, S., 2014. 
Studies on Physico-chemical characteristics of Tawa ana Halali reservoirs of Bhopal, India. Int. J. Current. Sci., 11: 70-83.

Murthuzasab, M.R., Rajasekar, M., Vijay Kumar, K. and Haliked, N.S. Seasonal variation in physico- chemical parameters of Hirahalla reservoir, Koppal Dist., Karnataka. Inter. J. Syst. Biol., 2010; 2(2): 16-20.

Parsons, T.R., Maitha, Y. and Lalli, C.M. A manual of chemical and biological methods for sea water analysis. Pergamon press, New york, pp.173; 1989.

Pawaiya, N., Sharma, D.K. and Khushwah, K.S. Analysis of Physico-chemical parameters in Harsi reservoir, Dabra, Gwalior, Madhya Pradesh. Int. J. Innov. Sci. Res., 2014; 11(2): 248-258.

Perumal, P. The influence of meteorological phenomena on the ecosystems of a tropical region, southeast coast of India. A case study. Ciencias Marinas, 1993; 19: 343-351.

Piska, R.S., Devi, S.B. and Divakara, K.C. The present status of Ibrahim, a minor reservoir of Hyderabad. Fishing Chimes, 2000; 20(2): 41-43.

Piska, R.S., Devi, S.B. and Divakara, K.C., 2000. The present status of Ibrahim, a minor reservoir of Hyderabad. Fishing Chimes, 20(2): 41-43.

Pulugandi, C. Analysis of water quality parameters in Vembakottai water reservoir, Virudhunagar district, Tamil Nadu, Res. J. Recent. Sci., 2014; 3:242-247.

Radhika, C.G., Mini, I. and Devi, T.G. Studies on abiotic parameters of a Tropical Fresh water lake - Vellayani lake, Trivandrum, Kerala. Pollu. Res., 2004; 23(1): 49-63.

Rathod, R.I., Balasaheb, P., Chavan R. and Pai, R.K. Variation in Primary Production In Relation to Physico- chemical parameters of Kadwai Reservoir, Ratnagiri, Maharashtra, India. Curr. World Environ., 2016; 11(1): 228-232.

Saxena, M. and Saksena, D.N. Water quality and trophic status of Raipur reservoir in Gwalior, Madhya Pradesh. J. Natural. Sci. Res., 2012; 2(8): 82-96.

Shiklomanov, I.A. World Water Resources: A new appraisal and assessment for the $21^{\text {st }}$ century. UK: UNESCO Cambridge University Press; 1998.

Shrotriy, V.P., Garg, R.K. and Saksena, D.N. Primary Production of Phytoplankton's in Oligomesotrohic Freshwater Body Harsi Reservoir and Their Potential Ecological Significance. Journal of Chemical, Biological and Physical Sciences., 2013; 4(1): 342-350.

Simpi, B., Hiremath, S.M., Murthy, K.N.S., Chandrasekarappa, K.N., Patel, A.N. and Puttaiah, E.T. Analysis of water quality using physico-chemical parameters, Hosahalli tank in Shimoga district, Karnataka, India. Glo. J. Sci. Fron. Res., 2011; 11(3): 31-34.

Sreenivasan, A. Principals of ecology and fisheries management in man-made lakes. In: Jhingran, A.G. and Sugunan, V.V. (eds.). Conservation and Management of Inland Fisheries Society of India. Inland Fisheries Society of India, CIFRI, Barrackpore; 1989.

Sreenivasulu, K., Hossain, K. and Daoodharam, T. Physico-chemical characteristics of freshwater Ramanna tank (cheruvu), Nellore district, India. Adv. Appl. Sci. Res., 2014; 5(2): 5965.

Srivastava, U.K., Desai, D.K., Gupta, V.K., Rao, S.S., Gupta, G.S., Raghavachari, M. and Vatsala, S. Inland fish marketing in India-Reservoir Fisheries, Concept Publishing Co., 
New Delhi, 4(A\&B): pp 403 and $1184 ; 1985$.

Sugunan, V.V. and Sinha, M. Guidelines for small reservoir fisheries management in India. Bull. No. 93, CICFRI, ICAR, Barrackpore; 2000.

Sugunan, V.V. and Yadava, Y.S. Hirakud reservoir-Strategies for fisheries development. Bulletin 66. CICFRI, Barrackpore, India; 1992.

Sugunan, V.V. Reservoir Fisheries in India. FAO Fish. Tech., paper No. 345, Rome: 1-423; 1995.

Sugunan, V.V. Reservoir Fisheries. Handbook of Fisheries and Aquaculture. ICAR, New Delhi; 2011.

sutulu, J.V.H. Render Indian Reservoirs Sustainability Fishful. Fishing Chimes, 1999; 19(2): 5-7.

Tembhare, D.R., 2015. Seasonal study of physico-chemical parameters of Kalisarar dam reservoir of Gondia district. Asian J. Anim. Sci., 10(1): 1419.
Thirumathal, K., Sivakumar, A.A., Chandrakantha, J. and Suseela, K.P. Physico-chemical studies of Amaravathy reservoir, Coimbatore district, Tamil Nadu. J. Ecobiol., 2002; 14(1): 13-17.

Thirupathaiah, M., Samatha, Ch. and Sammaiah, Ch. Analysis of water quality using Physico-chemical parameters in lower Manair reservoir of Karimnagar district, Andhra Pradesh. Int. J. Environ. Sci., 2012; 3(1): 172-180.

Vass, V.V., Sugunan, K.K. Status of Reservoir Fisheries in India. Status of Reservoir Fisheries in Five Asian Countries, NACA, Thailand; 2009.

WHO. World Health Organization. Guidelines for drinking water quality. Vol.2. Health Criteria and other supporting information, Geneva. ISBN 924-154169-5, 1984; pp: 327.

\section{How to cite this article:}

Chalapathi, K., Madhavi, K., Ramalingaiah, D., Jesintha, N., Adnan Amin, Gowri, G., Boda Satyanarayana, Sajhunnneesa Thirunilath and Jeshwanthi Jaini. 2018. Studies on Physicochemical Parameters of Kanigiri Reservoir, Nellore District, Andhra Pradesh. Int.J.Curr.Microbiol.App.Sci. 7(08): 979-996. doi: https://doi.org/10.20546/ijcmas.2018.708.111 